\title{
Resiko Investasi dalam Usaha Pendederan Ikan Patin (Pangasius hypothalamus) pada Akuarium di Kecamatan Kemang Kabupaten Bogor
}

\author{
[Risk of Investment in Patin Fish (Pangasius hypothalamus) nursery business in \\ the Aquarium in Kemang District, Bogor Regency]
}

\section{Paidi, Aan Hermawan}

SekolahTinggi Perikanan, Jurusan Penyuluhan Perikanan Jalan Cikaret Nomor 2 Bogor Selatan Kota Bogor 16132

\begin{abstract}
Abstrak
Kegiatan pendederan ikan patin menjadi salah satu usaha tersendiri pada budidaya perikanan. Suatu usaha mengandung resiko, salah satunya adalah resiko investasi. Setiap investasi yang dilakukan mengandung resiko atau ketidakpastian hasil. Penanam modalpun tidak tahu dengan pasti hasil yang akan diperolehnya dari investasi yang telah dilakukannya. Penelitian ini bertujuan untuk mengetahui hubungan keterkaitan resiko investasi dengan pendapatan yang diperoleh oleh pelaku usaha. Variabel pada penelitian ini adalah faktor internal perusahaan terdiri dari harga dan jumlah produksi. Tahapan prosedur penelitian dimulai dari pengadaan sarana prasarana produksi yang dilakukan pada tiga periode. Hasil penelitian pada tiga periode diperoleh Hasil pada periode pertama dan periode kedua tidak memperoleh keuntungan akan tetapi kegiatan masih dapat dilanjutkan pada periode ketiga. Tinggi rendahnya biaya investasi yang digunakan, tetap dapat memberikan ketidakpastian pada hasil yang diperoleh. Penyebab kejadian tersebut karena lebih dipengaruhi oleh faktor-faktor ketidakpastian, yaitu faktor teknis seperti . investasi, resio, pendapatan.
\end{abstract}

Kata kunci: Agribisnis, BEP, Payback periode, biaya produksi.

\begin{abstract}
Patin fish nursery activity is one of its own businesses in aquaculture. A business contains risks. One of them is investment risk. Every investment made contains a risk or an uncertain outcome. Even investors do not know for certain what the results will be obtained from the investment they have done. This study aims to determine the relationship of investment risk linkages with the income earned by business actors. The variable in this study is the company's internal factors consisting of price and production amount. The stages of the research procedure began with the procurement of production infrastructure which was carried out in three periods. The results of the study in the three periods obtained results in the first period and the second period did not benefit but the activity can still be continued in the third period. High and low investment costs used, can still provide uncertainty on the results obtained. The cause of the incident was because it was more influenced by uncertainty factors, namely technical factors such as investation, risk, and income.
\end{abstract}

Keywords: Agribusiness, BEP, payback periode, production cost.

\section{Penulis korespondensi}

Paidi | paidi.bogor@gmail.com 


\section{PENDAHULUAN}

Ikan patin (Pangasius hipophthalmus) mempunyai prospek yang baik dalam pemasaran ikan. Ikan ini mempunyai nilai ekonomis yang tinggi baik pada tingkat benih sebagai ikan hias maupun pada tingkat dewasa sebagai ikan konsumsi (Andriyanto, Tahapari, dan Insan 2012). Ikan patin telah lama dibudidayakan di Indonesia. Daerah penyebarannya meliputi Pulau Jawa, Sumatera, Kalimantan, Bali, Sulawesi dan lainnya. Ikan Patin mempunyai rasa yang enak, dagingnya tebal, mudah dibudidayakan serta bernilai ekonomis.

Budidaya ikan patin menunjukan kecenderungan meningkat disebabkan peningkatan permintaan pada ukuran konsumsi. Usaha pembesaran ikan patin dapat menghasilkan nilai revenue cost ratio $(R / C)$ atas biaya tunai yaitu 2,29 dan nilai $R / C$ atas biaya total yaitu 2,06 yang menunjukkan bahwa usaha ikan patin yang dilakukan menguntungkan dan layak untuk diusahakan karena nilai $\mathrm{R} / \mathrm{C}$ lebih dari 1 (Sazmi, Haryono, dan Suryani 2018). Hal tersebut berdampak pada peningkatan permintaan benih baik dari jumlah maupun mutu. Produksi benih patin di daerah Bogor di samping untuk memenuhi kebutuhan lokal yaitu Pulau Jawa, benih patin juga sebagian dikirim ke luar pulau, seperti Sumatera, Bali, Nusa Tenggara, dan Kalimantan.
Subsistem pendederan merupakan kelanjutan dari sistem pembenihan yang dilaksanakan dalam kegiatan budidaya (Hikmayani et al. 2003). Benih patin ukuran $3 / 4$ inchi diproduksi pada segmen usaha pendederan. Kegiatan tersebut dilakukan oleh para pembudidaya pada wadah akuarium pada hatchery indoor. Kegiatan biasanya dilakukan pada unitunit pembenihan rakyat (UPR) skala kelompok kecil atau keluarga baik sebagai usaha pokok atau hanya sebagai usaha sampingan.

Kegiatan pendederan ikan patin menjadi salah satu jenis usaha atau kegiatan usaha tersendiri. Dalam menjalankan suatu usaha ada banyak resiko-resiko yang ditemui, salah satunya adalah resiko investasi. Setiap investasi yang dilakukan mengandung resiko atau ketidakpastian hasil. Penanam modalpun tidak tahu dengan pasti hasil yang akan diperolehnya dari investasi yang telah dilakukannya (Husnan, 2009).

Investasi merupakan pengeluaran perusahaan secara keseluruhan yang mencakup pengeluaran untuk membeli bahan baku, mesin-mesin dan peralatan pabrik serta semua peralatan modal lain yang diperlukan dalam proses produksi (Lubis, Pardamen; Zulam 2016). Bentuk investasi dapat berupa aktiva riil dan aktiva keuangan. Investasi dalam suatu usaha juga dapat menimbulkan resiko- 
Tabel 1.Jadwal pelaksanaan teknis pendederan berdasarkan siklus.

\begin{tabular}{ccc}
\hline No & Periode & Waktu Pelaksanaan \\
\hline 1 & Periode 1 & 06 November - 29 November \\
2 & Periode 2 & 02 Desember - 09 Desember \\
3 & Periode 3 & 10 Desember - 31 Desember \\
\hline
\end{tabular}

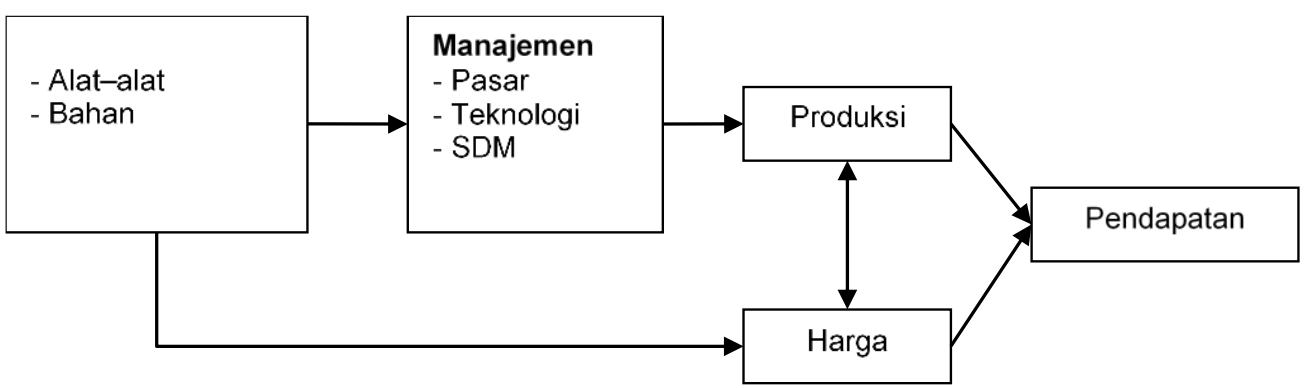

Gambar 1. Alur pikir

resiko tertentu yang berpengaruh pada investasi tersebut. Penelitian ini bertujuan untuk mengetahui hubungan keterkaitan resiko investasi dengan pendapatan yang diperoleh oleh pelaku usaha.

\section{BAHAN DAN METODE}

Kegiatan penelitian ini dilaksanakan mulai tanggal 6 November-31 Desember 2018 dengan rincian pelaksanaan yang terbagi atas 3 periode untuk memperoleh data yang diperlukan, adapun pelaksanaan masing - masing periode dapat dilihat pada Tabel 1. Alur pikir dapat dilihat pada Gambar 1.

Faktor penentu dari hasil akhir atau output bersih yang kemudian dinyatakan dalam bentuk nominal berupa pendapatan adalah besaran jumlah produksi dikalikan harga satuan. Variabel penelitian ini yaitu faktor internal perusahaan yang terdiri dari harga dan jumlah produksi. Bahan dan alat untuk pelaksanaan penelitian terinci pada Tabel 2 dan 3.

Tahapan prosedur penelitian dimulai dari pengadaan saprodi. Akuarium yang yang di gunakan pada penelitian ini adalah akuarium dengan

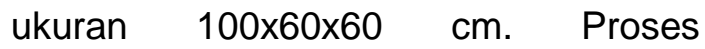
pendederan larva memerlukan wadah berupa akuarium berukuran 100×60×60 cm pada sistem rak (Sunarma 2007). Penelitian dilakukan pada tiga periode produksi. Periode 1 terdiri dari 50 akuarium, Periode 2 terdiri dari 30 akuarium, dan Periode ke 3 terdiri dari 30 akuarium. Setiap akuarium pada 
Tabel 2.Rincian bahan penelitian

\begin{tabular}{ll}
\hline No. & \multicolumn{1}{c}{ Nama Bahan } \\
\hline 1. & Larva Ikan Patin \\
2. & Pakan (Cacing Tubifex spp.) \\
3. & Obat-obatan \\
4. & Alat Tulis \\
\hline
\end{tabular}

Tabel 3.Peralatan untuk penelitian

\begin{tabular}{lll}
\hline No. & Nama Bahan \\
\hline 1. & Akuarium & \\
2. & Lambit & \\
3. & Timbangan \\
4. & Saringan Grading \\
5. & Hapa \\
\hline
\end{tabular}

kelompok penelitian dilakukan kegiatan meliputi: pengelolaan persiapan media, penebaran larva, pemeliharaan, pemanenan, dan pemasaran.

Rincian data-data yang di kumpulkan dari hasil pengamatan adalah total input yang meliputi:

1. Biaya Tetap

2. Biaya Variabel

3. Biaya Tenaga Kerja

Analisis yang dilakukan adalah:

1. Laba/Rugi

Analisis laba/rugi bertujuan untuk mengetahui apakah suatu usaha mendapat keuntungan atau mengalami kerugian. Perhitungan laba/rugi didapat dari selisih penerimaan dan pengeluaran (Kusuma dan Mayasti 2014; Rahim,
Supardi, dan Hastuti 2012). Suatu usaha yang menguntungkan akan memiliki nilai penerimaan lebih besar daripada total pengeluaran.

$$
\begin{gathered}
\pi=\mathrm{TR}-\mathrm{TC} \\
\pi=\text { keuntungan } \\
\mathrm{TR}=\text { penerimaan total } \\
\mathrm{TC}=\text { biaya total }
\end{gathered}
$$

\section{R/C Ratio}

Analisis R/C merupakan analisis untuk melihat keuntungan relatif suatu usaha dalam satu tahun terhadap biaya yang dikeluarkan dalam kegiatan tersebut. Analisis $\mathrm{R} / \mathrm{C}$ ratio atau Return and Cost ratio ( $\mathrm{R} / \mathrm{C}$ ratio) merupakan perbandingan antara nilai output terhadap nilai inputnya atau perbandingan antara 
penerimaan dan pengeluaran suatu usaha (Normansyah, Rochaeni, dan Humaerah 2014). Suatu usaha dikatakan layak bila R/C lebih besar dari 1 (R/C > 1). Hal ini menggambarkan semakin tinggi nilai $\mathrm{R} / \mathrm{C}$ maka tingkat keuntungan suatu usaha akan semakin tinggi.

$$
\begin{gathered}
\mathrm{R} / \mathrm{C}=\frac{\mathrm{TR}}{\mathrm{TFC}+\mathrm{TVC}} \\
\mathrm{TR}=\text { Total penerimaan } \\
\mathrm{TFC}=\text { Total biaya tetap } \\
\mathrm{TVC}=\text { Total biaya variabel }
\end{gathered}
$$

3. Break even point (BEP)

BEP adalah suatu titik jumlah produksi atau penjualan yang harus dilakukan agar biaya yang dikeluarkan dapat tertutupi kembali atau nilai dimana profit yang diterima adalah nol. Dengan kata lain, titik dimana besarnya penghasilan akan sama dengan total besarnya pengeluaran (Sugandi et al. 2019). Perumusan BEP adalah sebagai berikut:

$$
\text { BEP }(\text { Rupiah })=\frac{\text { Biaya Tetap }}{1-\frac{\text { Biaya Variabel }}{\text { pendapatan }}}
$$

$$
\text { BEP }(\text { Unit })=\frac{\text { Biaya Tetap }}{\text { Harga Jual- } \frac{\text { Biaya Variabel }}{\text { Unit }}}
$$

\section{Payback Period}

Payback Periode adalah suatu periode yang diperlukan untuk menutup kembali pengeluaran investasi (Rifani 2015). Analis payback period (PP) bertujuan untuk mengetahui jangka waktu tingkat pengembalian investasi yang telah ditanam pada suatu jenis usaha. Secara umum, PP dapat dihitung sebagai berikut.

$\mathrm{PP}=$ Total investasi : Keuntungan $\mathrm{x}$ 1 tahun

\section{HASIL DAN PEMBAHASAN}

Penelitian dilaksanakan pada salah satu unit pendederan Ikan Patin (Farm) lokal milik masyarakat setempat Kondisi geografis Kecamatan Kemang Kabupaten Bogor secara umum adalah memiliki Luas : 3.360,10 hektar dengan batas administratif:

- Sebelah Utara : Kecamatan Parung

- Sebelah Barat : Kecamatan Ciseeng

- Sebelah Selatan : Kecamatan Ranca Bungur

- Sebelah Timur : Kecamatan Tajur Halang

Kecamatan ini terdiri dari sat kelurahan dan delapan desa, yaitu : Atang Sanjaya, Semplak Barat, Parakan Jaya, Bojong, Kahuripan, Pabuaran, Tegal, Desa Pondok Udi, dan Jampang. Kegiatan ini dilaksanakan di Desa Kemang, Kabupaten Bogor. Informasi geografis suatu wilayah bermanfaat untuk menentukan jenis komoditas pertanian/perikanan, evaluasi keselarasan tata guna lahan pertanian/perikanan dan perencanaan 
wilayah tata ruang, dan analisis dan pemetaan degradasi area pertanian (Nahdi et al. 2013).

\section{Pendederan Ikan Patin Periode 1}

Pra produksi

Tahap pra produksi pada pendederan Ikan Patin adalah melakukan persiapan akuarium yang dimulai dari pembersihan akurium, akuarium yang akan digunakan dalam kegiatan pendederan Ikan Patin (Pangasius hypotalhamus), akuarium di cuci sampai bersih dengan disikat agar tidak terdapat kotoran maupun substrat dan material lain yang menempel, selanjutnya akuarium dikeringkan, setelah akuarium kering dilakukan pengecekan terhadap akuarium dengan mengisi air, akuarium diamati apabila terdapat kebocoran dilakukan perbaikan atau diganti dalam penelitian ini akuarium yang digunakan sebanyak 50 akuarium.

Selanjutnya adalah proses penataan dan penyusunan rak akuarium, dan pemasangan aerator/oksigen pada pendederan Ikan Patin, pada kegiatan pelaksaan yang diamati rak dipasang berjajar dan akuarium ditata diatas rak untuk memudahkan dalam proses produksi yaitu pemeliharaan pendederan sedangkan tabung yang digunakan sebanyak 4 buah dengan disambungkan menggunakan hiblow sebanyak 3 buah.
Selanjutnya dilakukan pengisian air guna dimanfatkan untuk kegiatan produksi. Aerator adalah salah satu upaya pengelolaan kualitas air untuk budidaya ikan. Kualitas air dengan kandungan oksigen yang optimal dapat meningkatkan pertumbuhan ikan dan prosentase ikan yang hidup (Patang, Nurmila, dan Wahab 2019).

\section{Proses produksi}

Kegiatan produksi pada periode satu ini meliputi penebaran benih /larva patin yang dimanfaatkan untuk pendederan Ikan Patin (Pangasius hypotalhamus), pada periode 1 menggunakan larva patin sebanyak 700.000 ekor, padat tebar setiap akuariumnya adalah 14.000 ekor setiap akuariumnya. Penentuan padat tebar yang optimal dapat mempengaruhi laju pertumbuhan dan bobot ikan patin selama budidaya (Marpaung, Usman, dan Lesmana 2017). Pemberian pakan terhadap larva patin dimulai dengan penggunaan pakan artemia, selama tiga hari dengan frekuensi empat kali. Selanjutnya dilakukan pemberian pakan berupa tubifex atau cacing sutera, dalam sehari pemberian pakan dilakukan dengan frekuensi sebesar lima kali dan semakin besar ukuran larva maka frekuensi pemberian pakan akan diberikan sebanyak tiga kali dalam sehari. Ketepatan frekuensi dan jenis 
pakan yang diberikan pada ikan patin dapat mempengaruhi pertumbuhan panjang, berat dan kelangsungan hidup ikan patin (Rangkuti, Aminah, dan Khotimah 2017).

Kegiatan yang dilakukan selanjutnya adalah kontrol kualitas air, karena ikan patin pada fase pendederan memiliki tingkat sensivitas yang tinggi maka kualitas air harus dipertahankan dengan cara melakukan pergantian air agar ikan patin tetap pada lingkungan yang baik. Kegiatan pemeliharaan ini berlangsung selama 18 hari, dengan besaran sintasan (survival rate) sebesar $17,6 \%$ dari 700.000 benih yang ditebar.

\section{Pasca Produksi}

Pasca produksi pada kegiatan pendederan ikan patin (Pangasius hypotalhamus), meliputi kegiatan pemanenan dan kegiatan pemasaran. Kegiatan pemanenan pada periode 1 dengan SR sebesar 17,6 \% maka jumlah benih yang berhasil didederkan sebanyak 123.300 ekor larva patin. Harga setiap ekornya adalah Rp. 65. Pemasaran merupakan pemasaran langsung, di mana pembeli membeli ke lokasi usaha. Pemasaran adalah hal yang sangat penting pada kegiatan ekonomi perikanan. Pemasaran di lokasi pasar dapat menimbulkan biaya baru yang berbeda pada setiap lokasi pasar (Tibrani 2015).

\section{Analisis Usaha Periode 1}

Analisis usaha pendederan ikan patin diuraikan pada Tabel 5 . Berdasarkan hasil pengamatan dalam satu periode kegiatan pendederan ikan patin dapat berlangsung paling sedikit selama 3 minggu atau 21 hari. Biaya tetap pada pendederan Ikan Patin dapat dilihat pada Tabel 6. Sedangkan biaya variabel atau biaya tidak tetap pada usaha pendederan ikan patin yang dilaksanakan dapat dilihat pada Tabel 7. 
Tabel 5. Biaya Investasi dan Penyusutan Pendederan Ikan Patin Periode 1

\begin{tabular}{llrrrrr}
\hline No & $\begin{array}{c}\text { Nama } \\
\text { Barang }\end{array}$ & $\begin{array}{c}\text { Jumlah } \\
\text { Barang }\end{array}$ & $\begin{array}{c}\text { harga } \\
\text { satuan }\end{array}$ & Harga Total & $\begin{array}{c}\text { JUE } \\
\text { (bulan) }\end{array}$ & Penyusutan \\
\hline 1 & Bangunan & 1 & 30.000 .000 & 30.000 .000 & 120 & 250.000 \\
2 & Akuarium & 50 & 150.000 & 7.500 .000 & 60 & 116.666 \\
3 & Rak Akuarium & 1 & 7.500 .000 & 7.500 .000 & 60 & 116.666 \\
4 & Tabung Gas & 4 & 150.000 & 600.000 & 24 & 25.000 \\
5 & Hiblow & 3 & 3.000 .000 & 9.000 .000 & 60 & 150.000 \\
& Jumlah & & & 54.600 .000 & & 658.332 \\
\hline
\end{tabular}

Tabel 6. Biaya Tetap Usaha Pendederan Ikan Patin Periode 1

\begin{tabular}{llcccr}
\hline No & Nama Barang & $\begin{array}{c}\text { Jumlah } \\
\text { Barang }\end{array}$ & Satuan & Harga Satuan & Harga total \\
\hline 1 & Tenaga Kerja & 1 & Orang & 3.000 .000 & 3.000 .000 \\
2 & Penyusutan & & & & 658.332 \\
\hline & Jumlah & & & & 3.658 .332 \\
\hline
\end{tabular}

Tabel 7. Biaya Variabel Usaha Pendederan Ikan Patin Periode 1

\begin{tabular}{llrlrr}
\hline No & Nama Barang & $\begin{array}{c}\text { Jumlah } \\
\text { Barang }\end{array}$ & Satuan & Harga Satuan & Harga total \\
\hline 1 & Larva Patin & 700.000 & Ekor & 8 & 5.600 .000 \\
2 & Artemia & 1 & Kaleng & 770.000 & 770.000 \\
3 & Pakan(Tubifex) & 200 & Takar & 15.000 & 3.000 .000 \\
4 & Garam Krosok & 48 & Kg & 5.000 & 240.000 \\
5 & El baju & 1 & Paket & 300.000 & 300.000 \\
6 & LPG & 20 & Tabung & 22.000 & 440.000 \\
\hline & Jumlah & & & & 10.350 .000 \\
\hline
\end{tabular}

Data yang diambil sebagai perhitungan awal sebelum dilakukan analisis usaha meliputi data dari total biaya yang di keluarkan serta pedapatan yang diperoleh sehingga dapat diketahui besaran keuntungan ataupun kerugian dari usaha pendederan ikan patin.

Total Biaya Produksi

Total biaya produksi yang dikeluarkan dalam usaha pendederan ikan patin yang dijalankan adalah :

Total Biaya Produksi = Biaya Tetap + Biaya Variabel 


$$
\begin{gathered}
=\text { Rp } 3.658 .332+\text { Rp. } 10.350 .000 \\
=\text { Rp. } 14.008 .332
\end{gathered}
$$

\section{Pendapatan}

Perhitungan pendapatan yang diterima dalam penderan ikan patin adalah hasil kali antara jumlah benih yang dihasilkan dalam satuan ekor dikalikan dengan harga benih patin dalam Rupiah (Rp.ekor ${ }^{-1}$ ).

Pendapatan = Jumlah Panen (ekor) $\mathrm{x}$

$$
\begin{gathered}
\text { Harga jual (Rp.ekor }{ }^{-1} \text { ) } \\
=123.300 \times \text { Rp. } 65 \\
=\text { Rp. } 8.014 .500
\end{gathered}
$$

Keuntungan /Kerugian

Kerugian yang diperoleh dari usaha pendederan ikan patin yang dilakukan, adalah :

Keuntungan $=$ Total Pendapatan - Total

$$
\text { Biaya }
$$

$$
\begin{gathered}
=8.014 .500-14.008 .332 \\
=- \text { Rp. } 5.993 .832
\end{gathered}
$$

Kegiatan Pendederan Ikan Patin ini memiliki resiko yang tinggi, sebab dalam pemeliharaannya ikan patin memiliki SR yang tergolong rendah yaitu sekitar $17,6 \%$ saja. Penelitian yang dilakukan oleh Ariyanto, Tahapari, dan Sularto (2012) menyebutkan bahwa umur benih ikan patin 5, 10, 15 hari yang ditebar pada kolam tidak berpengaruh terhadap sintasan, dan dapat mengahsilkan SR antara 54,53\%-71,49\%. Budidaya pendederan periode 1 belum mampu memperoleh keuntungan maka penelitian dilanjutkan pada periode 2 .

\section{Pendederan Ikan Patin Periode 2}

Pada periode 2 aspek teknis dan analisis usaha yang dilaksanakan merupakan lanjutan dari kegiatan Periode 1 yang belum memperoleh keuntungan sehingga dilakukan kembali proses Pendederan 2.

\section{Pra produksi}

Kegiatan pendederan ikan patin periode kedua merupakan lanjutan dari kegiatan pendederan ikan patin periode 1 yang belum memperoleh keuntungan, kegiatan teknis dilakukan sama seperti pada kegiatan pendederan 1 dimulai dari pembersihan akuarium, dan perbaikan terhadap sarana prasarana lain yang diperlukan apabila terjadi kerusakan.

Jumlah dari akuarium pada pendederan kedua ini yang digunakan adalah berjumlah 30 buah, kegiatan periode kedua ini dilaksanakan mulai tanggal 2 Desember 2018. Kegiatan selanjutnya adalah melakukan persiapan mulai dari penyiapan sarana dan prasarana serta melakukan kegiatan pembelian benih untuk selanjutnya di tebar pada akuarium yang sudah di persiapkan. 


\section{Proses produksi}

Kegiatan produksi pada periode 2 ini meliputi penebaran benih/larva patin yang dimanfaatkan untuk pendederan ikan patin (Pangasius hypotalhamus), pada periode kedua ini benih yang di tebar berjumlah 420.000 ekor untuk 30 akuarium. Pada awal kegiatan pendederan periode 2 ikan patin diberikan pakan berupa artemia selama 6 hari. Kendala terjadi saat kegiatan pemberian pakan berubah dari pakan artemia menjadi pakan berupa cacing sutra, larva. Permasalahan lain adalah benih Ikan Patin mengalami kematian, sehingga kegiatan produksi berhenti dilakukan, selanjutnya karena kematian Ikan Patin maka akuarium di bersihkan dan tidak dilanjutkan dan tidak terdapat panen.

Perubahan jenis pakan pada ikan patin ini sudah sesaui dengan perkembangan enzim pencernaan ikan patin. Effendi, Widanarni, and Augustine (2003) menjelaskan bahwa benih ikan patin umur 1 hari setelah menetas ternyata sudah mengandung enzim protease dan lipase di saluran pencernaannya. Perkembangan enzim pencernaan memiliki pola yang hampir sama pada setiap skedul pemberian pakan. Aktivitas protease, enzim lipase dan enzim amilase sesuai dengan waktu pertumbuhan ikan Perkembangan enzim pencernaan larva ikan patin ini sejalan dengan perkembangan (diferensiasi) anatomi saluran pencernaan. Saluran pencernaan benih patin berisi Artemia, cacing dan plankton dengan jumlah yang semakin meningkat dengan bertambahnya umur larva.

Kematian ikan patin adalah salah satu resiko dalam kegiatan budidaya Kematian dapat disebabkan oleh beberapa faktor yang tidak diteliti pada penelitian ini. diperoleh hasil bahwa terdapat enam faktor yang menjadi sumber risiko produksi, yaitu kesalahan dalam melakukan seleksi induk patin siam, kesalahan penyuntikan induk, 
Tabel 8. Biaya Investasi dan Penyusutan Pendederan Ikan Patin Periode 2

\begin{tabular}{llrrrrr}
\hline No & $\begin{array}{c}\text { Nama } \\
\text { Barang }\end{array}$ & $\begin{array}{c}\text { Jumlah } \\
\text { Barang }\end{array}$ & $\begin{array}{c}\text { harga } \\
\text { satuan }\end{array}$ & Harga Total & $\begin{array}{c}\text { JUE } \\
\text { (bulan) }\end{array}$ & Penyusutan \\
\hline 1 & Bangunan & 1 & 30.000 .000 & 30.000 .000 & 120 & 250.000 \\
2 & Akuarium & 30 & 150.000 & 4.500 .000 & 60 & 75.000 \\
3 & Rak Akuarium & 1 & 7.500 .000 & 7.500 .000 & 60 & 116.666 \\
4 & Tabung Gas & 4 & 150.000 & 600.000 & 24 & 25.000 \\
5 & Hiblow & 3 & 3.000 .000 & 9.000 .000 & 60 & 150.000 \\
\hline & Jumlah & & & 51.600 .000 & & 616.666 \\
\hline
\end{tabular}

Tabel 9. Biaya Tetap Usaha Pendederan Ikan Patin Periode 2

\begin{tabular}{clcccc}
\hline No & Nama Barang & $\begin{array}{c}\text { Jumlah } \\
\text { Barang }\end{array}$ & Satuan & Harga Satuan & Harga total \\
\hline 1 & Tenaga Kerja & 1 & Orang & 3.000 .000 & 3.000 .000 \\
2 & Penyusutan & & & & 616.666 \\
\hline & Jumlah & & & & 3.616 .666 \\
\hline
\end{tabular}

Tabel 10. Biaya Variabel Usaha Pendederan Ikan Patin Periode 2

\begin{tabular}{llclcr}
\hline No & Nama Barang & Jumlah Barang & Satuan & Harga Satuan & Harga total \\
\hline 1 & Larva Patin & 420.000 & Ekor & 8 & 3.360 .000 \\
2. & Artemia & 1 & Kaleng & 770.000 & 770.000 \\
& Jumlah & & & & 4.130 .000 \\
\hline
\end{tabular}

kanibalisme, musim kemarau, suhu air yang bersifat ekstrim yang dapat memicu kematian benih, dan penyakit (Manik 2013).

\section{Analisis Usaha Periode 2}

Analisis usaha pendederan ikan patin hanya sampai pada tahap produksi maka analisis usaha yang diuraikan dapat dilihat pada tabel 8. Biaya untuk kegiatan pendederan Ikan Patin pada Periode 2 tetap dikeluarkan dan dilakukan analisis sedangkan secara rinci besarnya biaya tetap pendederan Ikan Patin Periode 2 dapat dilihat pada tabel 9. Sedangkan biaya variabel atau biaya tidak tetap pada usaha pendederan Ikan Patin Periode 2 yang dilaksanakan dapat dilihat pada Tabel 10.

Berdasarkan hasil produksi pendederan ikan patin yang ada, dilakukan analisis usaha sebagai berikut: 


\section{Total Biaya Produksi}

Total biaya produksi yang dikeluarkan dalam usaha pendederan ikan patin yang dijalankan adalah :

Total Biaya Produksi = Biaya Tetap + Biaya Variabel

$=$ Rp 3.616.666 + Rp. 4.130.000

$$
=\text { Rp. } 7.746 .666
$$

\section{Keuntungan /Kerugian}

Kerugian yang diperoleh dari usaha pendederan ikan patin yang dilakukan pada periode 2 , adalah :

Keuntungan $=$ Total Pendapatan - Total Biaya

$$
\begin{gathered}
=\text { Rp. } 0 \text { - Rp. } 7.746 .666 \\
=- \text { Rp. } 7.746 .666
\end{gathered}
$$

Kegiatan pendederan ikan patin periode kedua ini mengalami kegalan yang sangat besar, karena benih yang dipelihara mati total, akan tetapi masih terdapat biaya lain yang memungkinkan untuk kegitan pendederan selanjutnya, maka dilakukan kegiatan pendederan ikan patin periode ke 3 .

\section{Pendederan Ikan Patin Periode 3}

Pada periode 3 aspek teknis dan analisis usaha yang dilaksanakan meliputi pra produksi, proses produksi dan paska produksi yang selanjutnya di lakukan analisis usaha, setelah mengalami kerugian dan kegagalan kegiatan pedederan Ikan Patin pada periode 3 dilaksanakan karena masih terdapat dana yang dapat dimanfaatkan untuk 1 siklus atau 1 periode kembali. kegiatan pendederan ikan patin periode 3 dilaksanakan mulai tanggal 10 Desember 2019. Kegiatan terbagi atas pra produksi, produksi dan pasca produksi.

\section{Pra produksi}

Kegiatan pendederan Ikan Patin periode ke 3 merupakan kegiatan pendederan Ikan Patin yang dilaksanakan dengan melanjutkan periode ke dua yang belum berhasil, secara teknis kegiatan dimulai dengan membersihkan akuarium yang digunakan untuk kegiatan pendederan Ikan Patin, akuarium dikeringkan dan di balik hingga tidak terdapat sisa air pada dinding kaca dan permukaan akuarium, selanjutnya air yang sudah disiapkan dimasukan dalam akuarium, kegiatan sama seperti periode 2 , jumlah akuarium yang digunakan adalah 30 buah.

Kegiatan selanjutnya adalah kegiatan pemesanan larva patin yang dipelihara selama 3 minggu atau 21 hari. Kegiatan pra produksi juga termasuk penyiapan sarana lain seperti penyiapan pakan, obat-obatan dan sarana pemeliharaan lain seperti tabung gas LPG. Pendederan ikan patin memerlukan perlakuan suhu yang baik, mengingat iklim di Kecamatan Kemang 
Kabupaten Bogor memasuki musim penghujan pada pelaksaan tanggal 1031 Desember 2018. Penaikkan suhu air budidaya ikan patin dilakukan dengan menghangatkan air menggunakan bahan bakar gas LPG tersebut. Beberapa pembudidaya menggunakan kompor dan lampu petromaks untuk mengatur suhu ruangan pembenihan. Hasil analisis usaha selama setahun dengan menggunakan kompor minyak tanah mampu memperoleh keuntungan sebesar $\operatorname{Rp} 52.996 .455,56$, nilai $R / C$ sebesar 1,97 dan payback period selama 1,73 tahun. Sedangkan analisis usaha dengan menggunakan lampu petromak, diperoleh keuntungan sebesar $\mathrm{Rp}$. 60.556.455,56, nilai R/C sebesar 2,28 dan payback period selama 1,52 tahun. Analisis finansial menghasilkan nilai NPV sebesar Rp 695.550.355,5, Net B/C sebesar $27,69 \%$ dan nilai IRR $457,26 \%$ (Diatin dan Dwirosyadha 2009). Suhu adalah faktor kritis pada pertumbuhan ikan patin sehingga perlu modifikasi suhu air untuk budidaya ikan patin (Islam et al. 2018).

\section{Proses produksi}

Kegiatan produksi pada periode 3 ini meliputi penebaran larva patin yang sudah dipesan sebelumnya, pada periode 1menggunakan larva patin sebanyak 420.000 ekor, padat tebar setiap akuariumnya adalah 14.000 ekor setiap akuariumnya. Pemberian pakan terhadap larva patin dimulai dengan penggunaan pakan artemia pada waktu awal pemeliharaan yaitu dalam periode 3 selama 6 hari, pemberian pakan artemia diberikan sebanyak 5 kali dalam sehari. Pada pukul 03:00, 08:00, 13:00, 17:00 dan pukul 22:00 WIB. Selanjutnya pemberian pakan menggunkan Tubifex sp. Pemberian pakan dilakukan sebanyak 4 kali dalam 1 hari. Berdasarkan kegiatan pelaksaan sintasan (SR) dari kegiatan ini mencapai $54,4 \%$ dari 420.000 ekor benih saat panen diperoleh jumlah individu panen sebanyak \pm 228.480 ekor untuk selanjutnya dilakukan pemanenan. Penelitian yang dilakukan oleh Budiardi, Rolin, dan Hadiroseyani (2014) menyebutkan evaluasi yang dilakukan pada pembudidaya pendederan ikan patin di Desa Sukamandijaya, Subang menghasilkan tingkat kelangsungan hidup ikan patin sebesar 56,04 $\pm 1,07 \%$, dan laju pertumbuhan bobot harian sebesar 27,96 $\pm 1,09 \%$. Penggunaan faktor input yang optimal adalah padat tebar 80 ekor. $\mathrm{L}^{-1}$ untuk larva dan pakan berupa cacing sutra dengan kepadatan $0,0919 \mathrm{~kg} \cdot \mathrm{L}^{-1}$.

\section{Pasca Produksi \\ Kegiatan pasca produksi kegiatan} pendederan ikan pati pada periode ke 3 meliputi kegiatan pemanenan dan 
Tabel 11. Biaya Investasi dan Penyusutan Pendederan Ikan Patin Periode 3

\begin{tabular}{llrrrrr}
\hline No & $\begin{array}{c}\text { Nama } \\
\text { Barang }\end{array}$ & $\begin{array}{c}\text { Jumlah } \\
\text { Barang }\end{array}$ & $\begin{array}{c}\text { harga } \\
\text { satuan }\end{array}$ & Harga Total & $\begin{array}{c}\text { JUE } \\
\text { (bulan) }\end{array}$ & Penyusutan \\
\hline 1 & Bangunan & 1 & 30.000 .000 & 30.000 .000 & 120 & 250.000 \\
2 & Akuarium & 30 & 150.000 & 4.500 .000 & 60 & 75.000 \\
3 & Rak Akuarium & 1 & 7.500 .000 & 7.500 .000 & 60 & 116.666 \\
4 & Tabung Gas & 4 & 150.000 & 600.000 & 24 & 25.000 \\
5 & Hi blow & 3 & 3.000 .000 & 9.000 .000 & 60 & 150.000 \\
\hline & Jumlah & & & 51.600 .000 & & 616.666 \\
\hline
\end{tabular}

Tabel 12. Biaya Tetap Usaha Pendederan Ikan Patin Periode 3

\begin{tabular}{|c|c|c|c|c|c|}
\hline No & Nama Barang & $\begin{array}{l}\text { Jumlah } \\
\text { Barang }\end{array}$ & Satuan & Harga Satuan & Harga total \\
\hline 1 & Tenaga Kerja & 1 & Orang & 3.000 .000 & 3.000 .000 \\
\hline \multirow[t]{2}{*}{2} & Penyusutan & & & & 616.666 \\
\hline & Jumlah & & & & 3.616 .666 \\
\hline
\end{tabular}

Tabel 13. Biaya Variabel Usaha Pendederan Ikan Patin Periode 3

\begin{tabular}{llccrr}
\hline No & Nama Barang & $\begin{array}{c}\text { Jumlah } \\
\text { Barang }\end{array}$ & Satuan & $\begin{array}{c}\text { Harga Satuan } \\
(\mathbf{R p})\end{array}$ & Harga total \\
\hline 1 & Larva Patin & 420.000 & Ekor & 8 & 3.360 .000 \\
2 & Artemia & 1 & Kaleng & 770.000 & 770.000 \\
3 & Pakan(Tubifex) & 100 & Takar & 15.000 & 1.500 .000 \\
4 & Garam Krosok & 24 & Kg & 5.000 & 120.000 \\
5 & El baju & $1 / 2$ & Paket & 300.000 & 150.000 \\
6 & LPG & 10 & Tabung & 22.000 & 220.000 \\
\hline & Jumlah & & & & 6.120 .000 \\
\hline
\end{tabular}

pemasaran, kegiatan pemanenan dilakukan pemanenan total, dari kegiatan produksi pemanenan pada kegiatan pendederan periode 3 benih yang dihasilkan sebanyak \pm 228.480 ekor, dikemas dan dilakukan pemasaran. Kegiatan pemasaran merupakan pemasaran langsung, dari produsen ke konsumen dengan 2 jalur, produsen mengantar ke lokasi usaha konsumen dan konsumen datang ke Farm pendederan secara langsung. Strategi pemasaran usaha agribisnis perikanan dapat dilakukan untuk optimalisasi hasil 
yang diinginkan. Salah satunya adalah memungkinkan distributor pada proses pendistribusian ikan. Terdapat 2 alternatif saluran distribusi dalam pendistribusian ikan yaitu pembudidaya $>$ distributor $>$ pengecer $>$ konsumen dan pembudidaya $>$ pengecer $>$ konsumen . Masalah yang sering dihadapi oleh pihak distributor adalah kekurangan persediaan ikan yang tidak bisa memenuhi permintaan pasar yang tinggi (Sundah, Jan, dan Sumarauw 2019).

\section{Analisis Usaha Periode 3}

Analisis usaha pendederan Ikan Patin pada periode 3 meliputi biaya produksi, pendapatan dan keuntungan diuraikan di tabel 11. Satu periode kegiatan pendederan Ikan Patin periode 3 dapat berlangsung paling selama 21 hari. Biaya tetap pada pendederan Ikan Patin dapat dilihat pada Tabel 12 . Pendederan Ikan Patin di Waduk Malahayu, Brebes, Jawa Tengah menghasilkan tingkat sintasan benih rata-rata yang diperoleh sebesar $98,76 \%$ dari jumlah tebar awal sebanyak 600.000 ekor. Setelah pemeliharaan selama 45 hari ukuran mencapai 4-5 inci atau $10 \mathrm{~g}$ dari ukuran awal benih 3/4-1 inci. Lama waktu pemeliharaan benih patin untu pendederan tergantung pada ukuran ikan patin yang diinginkan (Andriyanto et al. 2012). Biaya variabel atau biaya tidak tetap pada usaha pendederan ikan patin yang dilaksanakan dapat dilihat pada Tabel 13.

Berdasarkan hasil produksi pendederan ikan patin yang dilaksanakan pada periode 3 , hasil analisis usaha yang meliputi besaran biaya total (biaya tetap dan biaya tidak tetap) dan jumlah pendapatan/penghasilan kotor yang di peroleh serta keuntungan pada periode ke 3 diuraikan sebagai berikut:

\section{Total Biaya Produksi}

Total biaya produksi yang dikeluarkan dalam usaha pendederan Ikan Patin yang dijalankan adalah :

Total Biaya Produksi = Biaya Tetap + Biaya Variabel

$$
\begin{gathered}
=\text { Rp 3.616.666 + Rp. } 6.120 .000 \\
=\text { Rp. 9.736.666 }
\end{gathered}
$$

Total biaya produksi ikan patin dapat diefisienkan dengan beberapa faktor pada kondisi tertentu. Efisiensi faktor-faktor produksi usaha budidaya ikan patin (Pangasius pangasius) pada kondisi tertentu seperti pada penelitian Sumartin (2018). Penelitian ini menjelaskan efisiensi usaha para pembudidaya yang telah mengikuti pelatihan budidaya di BPPP Banyuwangi. Penggunaan faktor produksi luas kolam dan pupuk harus dikurangi. Penambahan kedua faktor produksi tersebut justru semakin meningkatkan ketidakefisienan. 
Penggunaan faktor produksi kapur, benih, pakan, dan probiotik masih bisa ditingkatkan. Penggunaan faktor produksi tenaga kerja ditambah, karena setiap penambahan satu satuan tenaga kerja akan mampu meningkatkan produksi sebesar $9,0545 \%$.

\section{Pendapatan}

Perhitungan pendapatan yang diperoleh dari kegiatan pendederan Ikan Patin periode 3 yang merupakan usaha perikanan yang dijalankan di Kecamatan Kemang, dan berdasarkan identifikasi, harga Rp.ekor ${ }^{-1}$ benih ikan patin mencapai Rp.65 ekor ${ }^{-1}$. Perhitungan nominal pendapatan dapat diamati sebagai berikut:

$$
\begin{gathered}
\text { Pendapatan }=\text { Jumlah Panen (ekor) } \mathrm{x} \\
\text { Harga jual }\left(\text { Rp ekor }^{-1}\right) \\
=228.480 \text { ekor } \times \text { Rp. } 65 \text { ekor }^{-1} \\
=\text { Rp. } 14.851 .200
\end{gathered}
$$

Keuntungan /Kerugian

Kerugian yang diperoleh dari usaha pendederan ikan patin yang dilakukan, adalah :

$$
\begin{gathered}
\text { Keuntungan }=\text { Total Pendapatan }- \\
\text { Total Biaya } \\
=14.851 .200-9.736 .666 \\
=\text { Rp. } 5.144 .534
\end{gathered}
$$

Kegiatan pendederan ikan patin baru memperoleh keuntungan pada periode ke 3. Kegiatan pendederan yang telah dilakukan dari 2 periode sebelumnya yang belum memperoleh keuntungan. Berdasarkan kelayakan usaha dapat diperoleh melalui perhitungan sebagai berikut.

Revenue Cost Ratio

$$
\begin{gathered}
\mathrm{RC}=\frac{\text { Pendapatan }}{\text { Total Biaya }} \\
=\frac{\text { Rp. } 14 \cdot 851 \cdot 200}{\text { Rp. } 9 \cdot 736 \cdot 666} \\
=1,5
\end{gathered}
$$

Setiap perhitungan $\mathrm{R} / \mathrm{C}$ dengan nilai lebih dari 1 artinya usaha tersebut layak untuk dijalankan. Artinya nilai perhitungan $\mathrm{R} / \mathrm{C}$ usaha pendederan Ikan Patin periode 1 mampu menghasilkan keuntungan sebanyak 1,5 kali dari biaya produksinya.

\section{Break Even Point (BEP)}

Break even point terdiri atas BEP rupiah/harga dan BEP unit yang dapat di analisis melalui perhitungan kelayakan usaha sebagai berikut:

$$
\begin{gathered}
\text { BEP (Rupiah) }=\frac{\text { Biaya Tetap }}{1-\frac{\text { Biaya Variabel }}{\text { pendapatan }}} \\
=\frac{\text { Rp. } 3 \cdot 616 \cdot 666}{1-\frac{\text { Rp. } 6 \cdot 120 \cdot 000}{\text { Rp. } 14 \cdot 851 \cdot 200}} \\
=\frac{\text { Rp. } 3 \cdot 616 \cdot 666}{1-0,41} \\
=\frac{\text { Rp. } 3 \cdot 616 \cdot 666}{0,59} \\
=\text { Rp. } 6 \cdot 129 \cdot 942
\end{gathered}
$$




$$
\begin{aligned}
\text { BEP }(\text { Unit })= & \frac{\text { Biaya Tetap }}{\text { Harga Jual- } \frac{\text { Biaya Variabel }}{\text { Unit }}} \\
& =\frac{\text { Rp. } 3.616 .666}{\text { Rp. } 65-26,7} \\
& =\frac{\text { Rp. } 3 \cdot 616.666}{\text { Rp. } 38,3} \\
& =94.430 \text { ekor }
\end{aligned}
$$

Perhitungan BEP (Break Even Point) rupiah dan unit, titik impas (tidak untung tidak rugi) terjadi apabila dengan pendapatan sebesar Rp. 6.129.942 dengan jumlah benih Ikan Patin sebanyak 94.430 ekor.

Return of Invesment (ROI)

$$
\begin{gathered}
\text { ROI }=\frac{\text { Keuntungan Usaha }}{\text { investasi }} \times 100 \% \\
=\frac{\text { Rp. } 5 \cdot 144 \cdot 534}{\text { Rp. } 51 \cdot 600 \cdot 000} \times 100 \% \\
=9,97 \%
\end{gathered}
$$

Keuntungan yang diperoleh dalam pendederan Ikan Patin periode 3 dapat mengembalikan modal sebesar 9,97\% dibulatkan menjadi $10 \%$.

\section{Payback Periode (PP)}

$$
\begin{gathered}
=\frac{\text { Modal Usaha }}{\text { Keuntungan Usaha }} \\
=\frac{\text { Rp. } 51 \cdot 600 \cdot 000}{\text { Rp. } 5 \cdot 514 \cdot 534} \\
=9,3 \text { siklus }
\end{gathered}
$$

Modal usaha dapat kembali dalam 10 kali siklus pendederan Ikan Patin, Jika dalam 1 bulan melakukan 1 kali siklus, secara berkelanjutan maka modal usaha dapat dikembalikan dalam waktu 10 bulan. Penentuan payback periode dalam usaha budidaya ikan adalah penting diketahui. Sistem pendukung keputusan pembudidaya dalam menentukan jenis budidaya ikan air tawar yang akan dilakukan yaitu dengan mempertimbangkan karakteristik lingkungan air dan payback periode pada analisis keuangan (Fitrony, Marisa, dan Wijaya 2019).

\section{SIMPULAN DAN SARAN}

\section{Simpulan}

Kegiatan penelitian yang telah dilaksanakan yaitu analisis resiko investasi pada pendederan Ikan Patin (Pangasius hypopthalmus) pada akuarium di Kecamatan Kemang Kabupaten Bogor. Penelitian dilaksanakan dalam tiga periode diperoleh hasil pada periode pertama dan periode kedua tidak memperoleh keuntungan akan tetapi kegiatan masih dapat di lanjutkan pada periode ketiga. Tinggi rendahnya biaya investasi yang digunakan, tetap dapat memberikan ketidakpastian pada hasil yang diperoleh. Hal tersebut karena lebih dipengaruhi oleh faktor-faktor ketidakpastian, yaitu faktor teknis seperti jenis pakan, padat tebar, kualitas air dan pemeliharaan.

Penyimpangan- 
penyimpangan yang terlalu besar dari faktor-faktor teknis berpengaruh pada hasil produksi sehingga dapat menimbulkan rendahnya hasil produksi yang kemudian berpengaruh pada pendapatan.

\section{Saran}

Saran yang dapat diberikan kepada pendeder Ikan Patin (Pangasius hypotalhamus) di Desa Kemang, Kecamatan Kemang Kabupaten Bogor adalah harus memiliki perencanaan produksi yang matang. Kegiatan untuk menghindari resiko ketidakpastian dari faktor-faktor teknis di lapangan, adalah dengan memanfaatkan ketersediaan biaya investasi agar dapat memberikan hasil yang maksimal yang berpengaruh pada peningkatan pendapatan.

\section{DAFTAR PUSTAKA}

Andriyanto, Septyan, Evi Tahapari, dan Irsyaphiani Insan. 2012. "Pendederan Ikan Patin di Kolam Outdoor untuk Menghasilkan Benih Siap Tebar di Waduk Malahayu, Brebes, Jawa Tengah." Media Akuakultur 7(1):20.

Ariyanto, Didik, Evi Tahapari, dan Sularto Sularto. 2012. "Keragaan Benih Ikan Patin Siam (Pangasianodon hypophthalmus) yang Ditebar Secara Langsung di Kolam pada Umur Berbeda." Jurnal Riset
Akuakultur 7(2):159.

Budiardi, Tatag, Febrina Rolin, dan Yani Hadiroseyani. 2014. "Evaluasi usaha pendederan ikan patin di Desa Sukamandijaya , Subang." Jurnal Akuakultur Indonesia 13(2):152-62.

Diatin, lis dan Ganang Arytra Dwirosyadha. 2009. "Analisis Finansial Penggunaan Lampu Petromak Sebagai Pemanas Pada Budidaya Pembenihan Ikan Patin." $J$ Bijak dan Riset Sosek KP 4(2):217-25.

Effendi, I., Widanarni, dan D. Augustine. 2003. "Perkembangan Enzim Pencernaan Larva Ikan Patin Pangasius hypophthalmus sp." Jurnal Akuakultur Indonesia 2(1):13-20.

Fitrony, Fachri Ayudi, Fitri Marisa, dan Indra Darma Wijaya. 2019. “istem Pendukung Keputusan Rekomendasi Budidaya Ikan Air Tawar Menggunakan Metode Topsis Dan Analisis Keuangan Payback Periode." Jurnal SPIRIT 11(1):30-38.

Hikmayani, Yayan, Sonny Koeshendrajana, Abdul Wahid, dan Zahri Nasution. 2003. "Aspek Sosial Ekonomi dan Kelembagaan Sistem Usaha Perikanan (SUP) Budidaya Ikan Patin di Propinsi Jawa Barat." 
Jurnal Penelitian Perikanan Indonesia 9(6):11-22.

Islam, Md. Ariful, Md. Jasim Uddin, Helal Uddin, dan Md. Shahjahan. 2018. "Effects of Temperature on Growth and Hematological Parameters in Thai pangas, Pangasianodon hypophthalmus." Hal. Md. Ariful Islam in Conference: International Conference on Challenges for Future Agriculture arranged by Progresive Agriculturists, At Bangladesh Agricultural University, Mymensingh.

Kusuma, Parama Tirta Wulandari Wening dan Nur Kartika Indah Mayasti. 2014. "Analisa Kelayakan Finansial Pengembangan Usaha Produksi Komoditas Lokal: Mie Berbasis Jagung." agriTECH 34(2):194-202.

Lubis, Pardamen; Zulam, S. B. 2016.

"Analisis Faktor-Faktor Yang Mempengaruhi Permintaan Investasi Di Indonesia." 2(2):14766.

Manik, Harry Setiyadi Ginting. 2013. "Analisis Risiko Produksi Benih Ikan Patin Siam (Pangasius hypopthalmus) pada Elminari Fish Culture (Efc) Di Desa Kampung Kondang Kecamatan Ciampea Kabupaten Bogor Jawa Barat." IPB Bogor.
Marpaung, Andreas H., Syammaun Usman, dan Indra Lesmana. 2017. "Pengaruh Padat Tebar Terhadap Laju Pertumbuhan Ikan Patin ( Pangasius pangasius )." AQUACOASTMARINE 5(2):11226

Nahdi, Zed, Hendy Hendro, Hadi Supriyo, dan Budi Gunawan. 2013. "Pemetaan Dan Inventarisasi Data Komoditas Pertanian Dan Informasi Kondisi Lahan Di Kabupaten Kudus Berbasis Sistim Informasi Geografis." Jurnal Sains dan Teknologi 6(1):33-38.

Normansyah, Dodi, Siti Rochaeni, dan Armaeni Dwi Humaerah. 2014. "Analisis Pendapatan Usahatani Sayuran Di Kelompok Tani Jaya, Desa Ciaruteun Ilir, Kecamatan Cibungbulang, Kabupaten Bogor." Agribusiness Journal 8(1):29-44.

Patang, Nurmila, dan Muh. Ilham A. Wahab. 2019. "Modifikasi Aerasi terhadap Peningkatan Oksigen Terlarut yang Mempengaruhi Tingkat Pertumbuhan dan Sintasan pada Ikan Nila (Oreochrobis Niloticus) Modification." Jurnal Pendidikan Teknologi Pertanian 5(2):65-72.

Rahim, Abd, Suprapti Supardi, dan Diah Retno Dwi Hastuti. 2012. Model Analisis Ekonomika Pertanian. Makassar (ID): Badan Penerbit 
Universitas Negeri Makassar.

Rangkuti, Mahbub Jalil, lin Siti Aminah, dan Khusnul Khotimah. 2017. "Pemberian Beberapa Jenis Pakan Dengan Frekuensi Yang Berbeda Pada Benih Ikan Patin Siam (Pangasius hypophthalmus)." Fisheries 6(1):17-23.

Rifani, Akhmad. 2015. "Analisis Kelayakan Finansial Usaha Peternakan Ayam Pedaging di Sentra Produksi Ayam Kabupaten Lampung Tengah (Studi Kasus di Sentra Produksi Ayam Kecamatan Kalirejo)."

Sazmi, Ramon Musikal, Dwi Haryono, dan Ani Suryani. 2018. "Analisis Pendapatan Dan Efisiensi Pemasaran Ikan Patin Di Kecamatan Seputih Raman Kabupaten Lampung Tengah." JIIA 6(2):133-41.

Sugandi, Wahyu Kristian, Handarto

Handarto, Totok Herwanto, dan Chandra Irfan Hanif. 2019. "Uji Kinerja dan Analisis Ekonomi Mesin Penanam Padi (Studi Kasus Desa Mekarluyu, Kecamatan Sukawening, Kabupaten Garut, Jawa Barat)." Jurnal Ilmiah Rekayasa Pertanian dan Biosistem. Sumartin. 2018. "Analisis Efisiensi Faktor-Faktor Produksi Usaha Budidaya Ikan Patin ( Pangisius pangasius ) ( Studi Kasus Pada Alumni Peserta Pelatihan Budidaya Ikan Di BPPP Banyuwangi ) Analysis Efficiency of Production Factors of Business Aquaculture of Catfish ( Pangi." Intek Akuakultur 2(1):16-34.

Sunarma, A. D. E. 2007. "Panduan Singkat Teknik Pembenihan Ikan Patin ( Pangasius hypophthalmus )." Sundah, Djamaludin, Arrazi Bin Hasan Jan, dan Jacky S. B. Sumarauw. 2019. "Analisis Saluran Distribusi Ikan Mujair Desa Matungkas Kecamatan Dimembe Kabupaten Minahasa Utara." Jurnal EMBA $7(1): 251-60$.

Tibrani. 2015. "Analisis Sistem Pemasaran Ikan Patin Segar Desa Koto Mesjid Ke Daerah Tujuan Pemasaran." Jurnal Dinamika Pertanian 30(3):273-82. 